\title{
In Vitro Effects of Brassinosteroids on the Growth and Antioxidant Enzyme Activities in Groundnut
}

\author{
Aman Verma, ${ }^{1}$ C. P. Malik, ${ }^{1}$ and V. K. Gupta ${ }^{2}$ \\ ${ }^{1}$ School of Life Sciences, Jaipur National University, Jaipur 302025, India \\ ${ }^{2}$ Department of Biochemistry, Kurukshetra University, Kurukshetra 136119, India \\ Correspondence should be addressed to Aman Verma, verma.aman1980@gmail.com
}

Received 11 August 2011; Accepted 14 September 2011

Academic Editors: H. Raman and D. S. Virk

Copyright (C 2012 Aman Verma et al. This is an open access article distributed under the Creative Commons Attribution License, which permits unrestricted use, distribution, and reproduction in any medium, provided the original work is properly cited.

\begin{abstract}
This paper deals with the in vitro effects of brassinosteroids (BRs) on growth in the form of multiple shoots, chlorophyll content, Hill reaction activity (HRA), activities of catalase (CAT), peroxidase (POX), polyphenol oxidase (PPX), and ascorbate peroxidase (APX) in Arachis hypogaea L. genotypes (M-13 and PBS24030). In vitro impact of BR on shoot multiplication potential was found to be the best at $1 \mathrm{~mL} \mathrm{~L}^{-1}$ with BA $\left(3 \mathrm{mg} \mathrm{L}^{-1}\right)$ in both the cultivars. Flowering was observed in PBS24030 on the medium containing $2.0 \mathrm{~mL} \mathrm{~L}^{-1} \mathrm{BR}$ with $3 \mathrm{mg} \mathrm{L}^{-1}$ BA. Rhizogenesis was noticed in the presence of BR alone. Total chlorophyll content and HRA were highest at $2.0 \mathrm{~mL} \mathrm{~L}^{-1}$ with BA in $\mathrm{M}-13$ and $1.0 \mathrm{~mL} \mathrm{~L}^{-1}$ with BA in PBS24030. Antioxidant enzyme activities were increased in the presence of BR whether alone or in combination with BA in both the cultivars. However, progressive decline was observed in case of MDA content. The results obtained in the study clearly indicated not only the in vitro establishment of groundnut cultivars in the presence of BR alone and in combination with BA but also its effect on various growth promotory physiological parameters.
\end{abstract}

\section{Introduction}

Oilseed crops form the backbone of agricultural economy of India. Oilseed crops and their products are the second most sold commodities in the world trade. In India, groundnut (Arachis hypogaea L.) was cultivated in an area of 6.22 million ha yielding $1180 \mathrm{Kg} / \mathrm{ha}$ in 2008-2009 (http://agricoop.nic.in/Agristatistics.htm). Besides income for the farmers, groundnut provides an inexpensive source of high-quality nutrition. Groundnut seeds contain $44-56 \%$ oil and $22-30 \%$ protein on a dry seed basis [1]. Although India is the world's largest producer of edible oils yet it imports large quantities of oils ( $\sim 1.2$ million tons). One of the reasons for India's large edible oil deficit is the poor yield of oilseed crops per hectare, principally caused by the available cultivars being susceptible to diseases and vulnerable to abiotic stresses as well as poor farm practices. Therefore, it would be pertinent to assess the potential of new genotypes of peanut in the in vitro conditions and new combination of PGRs for regeneration and biochemical manipulation.
Brassinosteroids (BRs) are common plant-produced compounds structurally similar to animal steroid hormones that can function as growth regulators [2]. In addition, it has been suggested that BRs could be included in the category of phytohormones [3]. Exogenous application of BRs affects a broad spectrum of physiological responses like cell expansion, vascular differentiation, reproductive development, seed germination, flowering, and fruit set in plants [4-6]. Apart from growth-promoting effects, BRs are also reported to confer resistance to plants against various abiotic and biotic stresses like heat, drought, heavy metals, infections, pesticides, salt, and even viruses [7-10]. Nunez et al. [11] and Özdemir et al. [12] observed that resistance to the stresses involves regulation of antioxidative enzyme activities under the influence of these plant growth regulators. Although innumerable works have confirmed the potential of the plant hormones to synergistically improve crop performance under normal conditions, very little light has been thrown on the influence of BRs under the in vitro condition. In view of this fact, the purpose of the present study was to increase our understanding of the effects of BR 
on micropropagation and alterations of various biochemical characteristics in groundnut.

\section{Materials and Methods}

Groundnut genotypes, M-13 (Spreading type), and PBS24030 (Semi-spreading type) were procured from Agricultural Research Station (ARS), Durgapura, Jaipur, India. The seeds were washed with tap water for $10-15 \mathrm{~min}$ followed by immersion in liquid detergent solution labolene for $5 \mathrm{~min}$. After washing with distilled water, the seeds were again immersed with $70 \%$ ethanol for 3-5 min and rinsed with distilled water three to four times. Then, the seeds were brought to the inoculation chamber and surface sterilized with $0.1 \% \mathrm{HgCl}_{2}$ for $8 \mathrm{~min}$ and rinsed with sterile distilled water for 3-4 times. Four-to-six surface-sterilized seeds were germinated aseptically in a $250 \mathrm{~mL}$ wide mouthed conical flask having sterilized wet cotton bed in dark. Based on our previous finding, cotyledonary node $(\mathrm{CN})$ was excised from 10-12 days old seedling and used as explants [13]. Such explants were cultured on MS medium [14] containing $3 \%(\mathrm{w} / \mathrm{v})$ sucrose and varying concentrations $(0.5,1.0$, and $2.0 \mathrm{~mL} \mathrm{~L}^{-1}$ ) of Double (a commercial formulation of BR), procured from Godrej Agrovet Ltd., Sachin, India, alone and in combination with $\mathrm{BA}\left(3 \mathrm{mg} \mathrm{L}^{-1}\right)$. $\mathrm{CN}$ explant was inoculated and cultures were incubated at $24 \pm 2{ }^{\circ} \mathrm{C}$ under $16 \mathrm{~h}$ exposures to white light of $80 \mu \mathrm{Em}^{-2} \mathrm{~s}^{-1}$ intensity provided by fluorescent tubes for 4-5 weeks for multiple shooting. Control set was devoid of any PGR. Shooting potential of this PGR was recorded after 40 DAI.

\section{Biochemical and Enzymatic Estimations}

Estimation of biochemical parameters and enzyme activity was carried in the in vitro grown 25-30 days old leaves from lateral branches. Total chlorophyll content was estimated by the method of Coombs et al. [15]. Hill reaction activity (HRA) was determined according to Cherry [16]. For estimation of antioxidative enzyme activities, one gram of in vitro grown 25-30 days old leaves were homogenized in $10 \mathrm{~mL}$ of the extraction buffer composed of $50 \mathrm{mM}$ potassium phosphate buffer ( $\mathrm{pH} 7.0$ ), $10 \mathrm{~g} \mathrm{~L}^{-1} \mathrm{PVP}, 0.2 \mathrm{mM}$ EDTA, and $10 \mathrm{mM}$ Triton X-100. The resulting homogenate was centrifuged at $12,000 \times \mathrm{g}$ for $20 \mathrm{~min}$ at $4^{\circ} \mathrm{C}$ and the supernatant was used for the determination of catalase (CAT), ascorbate peroxidase (APX), peroxidase (POX), and polyphenol oxidase (PPX) activities. CAT activity was determined by following the initial rate of disappearance of $\mathrm{H}_{2} \mathrm{O}_{2}$ at $240 \mathrm{~nm}$ [17]. APX activity was measured by the amount required to decompose $1 \mu \mathrm{mol}$ ascorbic acid oxidized $\mathrm{min}^{-1}$ [18]. POX and PPX activity was assayed adopting the method of Kar and Mishra [19]. One unit (U) of POX and PPX activity was defined as the amount of enzyme that caused an increase in absorbance at $420 \mathrm{~nm}$ of 0.01 per min. Lipid peroxidation was determined as the content of malondialdehyde (MDA) using the thiobarbituric acid reaction as described by Moshaty et al. [20]. Total soluble sugars and proteins were estimated following the method of Clegg [21] and Lowry et al. [22], respectively.
Each growth experiment was conducted thrice taking three replicas of each treatment, under in vitro conditions. The data from all experiments were pooled together and analyzed for analysis of variance (ANOVA) with genotypes, BR treatments, and their interactions included as the possible sources of variation by SAS system.

\section{Results}

4.1. Effect of BR on Multiple Shoot Induction. The observations made on morphological parameters indicated that the treatments of BR significantly improved growth. Statistical analysis showed that the shooting potential in both the genotypes was highly significant at $P<0.01$ (Table 1). In M13 , multiplication potential revealed an enhancement with the increasing concentrations of $\mathrm{BR}$ alone. The most effective response was noticed on the medium containing $1 \mathrm{mLL}^{-1}$ BR with BA $\left(3 \mathrm{mg} \mathrm{L}^{-1}\right)$ which was $\sim 11$ folds (M-13) and 24 folds (PBS24030) greater than the control (Figure 1(a)). A significant level of shoot elongation was found at $0.5 \mathrm{~mL} \mathrm{~L}^{-1}$ $\mathrm{BR}$ alone in both the cultivars. Extensive flowering was observed in PBS24030 on the medium containing $2.0 \mathrm{~mL} \mathrm{~L}^{-1}$ BR with $3 \mathrm{mg} \mathrm{L}^{-1}$ BA (Figure 2(a)). Rhizogenesis was noticed in the presence of $\mathrm{BR}$ alone particularly at low concentrations. In M-13 cultivar, $0.5 \mathrm{~mL} \mathrm{~L}^{-1} \mathrm{BR}$ (Figure 2(b)), and in PBS24030, 1.0 and $2.0 \mathrm{~mL} \mathrm{~L}^{-1}$ BR treatments showed rooting within 7-10 DAI. BR-treated cultures failed to produce roots in the presence of BA. Well-rooted plantlets were transferred to thermocol pots (Figure 2(c)) and then to field condition.

4.2. Effect of BR on Total Chlorophyll Content. The data showed that the application of BR enhanced the chlorophyll content in both the cultivars and the elevation was greater when BR was used in combination with BA (Figure 1(b)). When used singly, the most effective concentration of BR was $1.0 \mathrm{~mL} \mathrm{~L}^{-1}$ in $\mathrm{M}-13$ and $2.0 \mathrm{~mL} \mathrm{~L}^{-1}$ in PBS24030. It was apparent from the above results that the combined application of BR and BA exerted a positive effect $(P<0.01)$ on chlorophyll content in groundnut. However, interaction among the genotypes and concentrations of PGRs used was significant at $P<0.05$ (Table 1).

4.3. Effect of BR on Hill Reaction Activity (HRA). Increase in HRA was more pronounced when BR was added along with BA in both the cultivars as compared to control $(P<0.01)$. In M-13 cultivar, the highest HRA was recorded in the presence of $2.0 \mathrm{~mL} \mathrm{~L}^{-1} \mathrm{BR}$ along with $\mathrm{BA}\left(3 \mathrm{mg} \mathrm{L}^{-1}\right)$ as compared to the control (Figure 1(c)). On the other hand, the highest

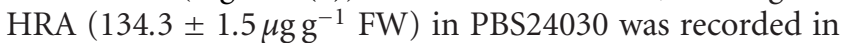
the presence of $1.0 \mathrm{~mL} \mathrm{~L}^{-1} \mathrm{BR}$ along with $\mathrm{BA}\left(3 \mathrm{mg} \mathrm{L}^{-1}\right)$.

4.4. Effect of BR on Catalase (CAT) Activity. Among all the treatments of $\mathrm{BR}$ alone and in combination, $1.0 \mathrm{~mL} \mathrm{~L}^{-1}$ resulted in the highest activity of CAT in M-13 whereas $2.0 \mathrm{~mL} \mathrm{~L}^{-1}$ BR alone and in combination was inhibitory. In PBS24030, CAT activity, enhanced with the increasing concentration of $B R$ reaching the maximum at $2.0 \mathrm{~mL} \mathrm{~L}^{-1}$ BR alone and $1.0 \mathrm{~mL} \mathrm{~L}^{-1} \mathrm{BR}$ with BA (Figure $1(\mathrm{~d})$ ). 
TABLE 1: ANOVA table for different biochemical characteristics from the in vitro grown leaves sampled from 25 days old culture of two groundnut genotypes (M-13 and PBS24030) treated with different concentrations of Brassinosteroid (BR) alone $\left(0.5,1,0,2.0 \mathrm{~mL} \mathrm{~L}{ }^{-1}\right)$ and in combination with 6-Benzyl Adenine (BA, $\left.3 \mathrm{mg} \mathrm{L}^{-1}\right)$.

\begin{tabular}{|c|c|c|c|c|c|c|c|c|c|c|}
\hline \multirow[b]{2}{*}{ Source } & \multicolumn{10}{|c|}{ Mean squares } \\
\hline & $\begin{array}{l}\text { Shooting } \\
\text { potential }\end{array}$ & $\begin{array}{c}\text { Chl. } \\
\text { content }\end{array}$ & HRA & CAT activity & $\begin{array}{c}\text { POX } \\
\text { activity }\end{array}$ & $\begin{array}{c}\text { PPX } \\
\text { activity }\end{array}$ & $\begin{array}{c}\text { APX } \\
\text { activity }\end{array}$ & $\begin{array}{c}\text { MDA } \\
\text { content }\end{array}$ & $\begin{array}{l}\text { Total } \\
\text { carb. } \\
\text { content }\end{array}$ & $\begin{array}{l}\text { Total } \\
\text { protein } \\
\text { content }\end{array}$ \\
\hline Genotype & $379.68^{* *}$ & $0.009^{*}$ & $25750.18^{* *}$ & $2569122.14^{* *}$ & $374.083^{* *}$ & $120.33^{*}$ & $533.36^{* *}$ & $1912.68^{* *}$ & $35.03^{* *}$ & $0.013^{* *}$ \\
\hline PGR & $1463.02^{* *}$ & $0.107^{* *}$ & $76485.35^{* *}$ & $1578113.87^{* *}$ & $1452.000^{* *}$ & $833.33^{* *}$ & $308.44^{* *}$ & 22.68 & $2515.56^{* *}$ & $0.282^{* *}$ \\
\hline Concentration & $555.40^{* *}$ & $0.011^{* *}$ & $14709.76^{* *}$ & $266007.85^{* *}$ & $473.027^{* *}$ & $765.36^{* *}$ & $188.27^{* *}$ & 251.57 & $582.04^{* *}$ & $0.033^{* *}$ \\
\hline $\begin{array}{l}\text { Genotype* } \\
\text { PGR }\end{array}$ & 67.68 & 0.001 & $7451.19^{* *}$ & $31834.56^{* *}$ & 0.000 & 2.08 & $96.09^{* *}$ & 111.02 & $397.59^{* *}$ & $0.018^{* *}$ \\
\hline $\begin{array}{l}\text { Genotype* } \\
\text { Concentration }\end{array}$ & 50.35 & $0.006^{*}$ & $2446.68^{* *}$ & $85281.45^{* *}$ & $421.138^{* *}$ & 23.50 & $18.70^{* *}$ & 322.63 & $278.14^{* *}$ & 0.002 \\
\hline $\begin{array}{l}\text { PGR* } \\
\text { Concentration }\end{array}$ & $559.46^{* *}$ & 0.001 & $2211.65^{* *}$ & $106753.06^{* *}$ & $63.166^{*}$ & $140.94^{* *}$ & $289.45^{* *}$ & 148.40 & $103.88^{* *}$ & 0.002 \\
\hline $\begin{array}{l}\text { Genotype* } \\
\text { PGR* } \\
\text { Concentration }\end{array}$ & 25.35 & $0.008^{* *}$ & $461.81^{* *}$ & $32399.98^{* *}$ & $72.833^{* *}$ & 35.80 & $44.03^{* *}$ & 27.85 & $77.91^{* *}$ & 0.001 \\
\hline
\end{tabular}

* Significant at $5 \%$ level,

** Significant at $1 \%$ level.

4.5. Effect of BR on Peroxidase (POX) Activity. When BR alone was applied, the maximum activity was observed at 0.5 and $1.0 \mathrm{~mL} \mathrm{~L}^{-1}$ BR in M-13 and PBS24030, respectively $(P<0.01$; Table 1). On treatment with both BR and $\mathrm{BA}$, the activity of POX showed an increase in both the cultivars in comparison with untreated control, however, when compared with BA alone, the increase was noticed only in PBS24030 (Figure 1(e)). However, genotypic variations were noticed in the two cultivars.

4.6. Effect of BR on Polyphenol Oxidase (PPX) Activity. The activity of PPX was the highest at $2.0 \mathrm{~mL} \mathrm{~L}^{-1} \mathrm{BR}$ along with BA $\left(3 \mathrm{mg} \mathrm{L}^{-1}\right)$ in both the cultivars $(P<0.01)$. It was apparent from the data that the combined treatment with $\mathrm{BR}$ and BA was more effective in augmenting PPX activity as compared to BA alone. The increase in activity at $2.0 \mathrm{~mL} \mathrm{~L}^{-1}$ $\mathrm{BR}$ alone and in combination with BA compared to the control was $66 \%$ and $103 \%$ in $\mathrm{M}-13$ and $72 \%$ and $148 \%$ in PBS24030, respectively (Figure 1(f)).

4.7. Effect of BR on Ascorbate Peroxidase (APX) Activity. The effect of BR alone or in combination with BA on APX activity was highly significant at $P<0.01$ (Table 1 ) in both the cultivars. In M-13, the activity of APX increased markedly under the influence of BR; however, a decrease in activity was noticed at $2.0 \mathrm{~mL} \mathrm{~L}^{-1} \mathrm{BR}$ (Figure $1(\mathrm{~g})$ ). In PBS24030 also, an elevation in the APX activity was noticed up to $1.0 \mathrm{~mL} \mathrm{~L}^{-1} \mathrm{BR}$ but thereafter, the activity showed a decline. The treatment with BR in combination with BA lowered the activity of APX as compared to $\mathrm{BR}$ and $\mathrm{BA}$ used alone.

4.8. Effect of BR on Malondialdehyde (MDA). The content of MDA was reduced in the in vitro grown leaves of groundnut plants sampled from 25 days old culture treated with BR alone and along with BA $\left(3.0 \mathrm{~mL} \mathrm{~L}^{-1}\right)$ in both $\mathrm{M}-13$ and PBS24030 cultivars of groundnut (Figure $1(\mathrm{~h})$ ). In general, the decline was greater when BR was applied in combination with BA. Furthermore, the pattern of reduction was different in the two genotypes. The cultivar PBS24030 exhibited a greater decline as compared to M-13. Only the genotypic differences were found to be statistically significant (Table 1).

4.9. Effect of BR on Total Soluble Carbohydrate and Protein Contents. Influence of BR was found to be significant on the level of total soluble carbohydrates and proteins in both the cultivars $(P<0.01)$. In $\mathrm{M}-13$, the total soluble carbohydrates content registered an increase upon treatment with BR alone; however, when BR was applied along with BA, an increase was noticed up to $1.0 \mathrm{~mL} \mathrm{~L}^{-1}$ BR. In PBS24030, it was apparent that treatment with BR alone as well as in combination increased the total soluble carbohydrates substantially. The accumulation of carbohydrates in the treated leaves was more in PBS24030 than M-13 genotype (Figure 1(i)). The total soluble protein content enhanced $(P<0.01)$ with the increasing concentrations of $\mathrm{BR}$ alone as well as in combination with BA in both the cultivars (Figure $1(\mathrm{j})$ ).

\section{Discussion}

BRs are known to induce a broad spectrum of responses, including stimulation of longitudinal growth of young tissues via cell elongation and cell division $[23,24]$ and vascular differentiation, which is a developmental process critical for plant growth. In the present studies, BR effectively stimulated the elongation and formation of lateral shoots and shoot buds. Similar results were reported by PereiraNetto et al. $[25,26]$ in Eucalyptus and Malus prunifolia. The difference in the shooting response of the two genotypes 


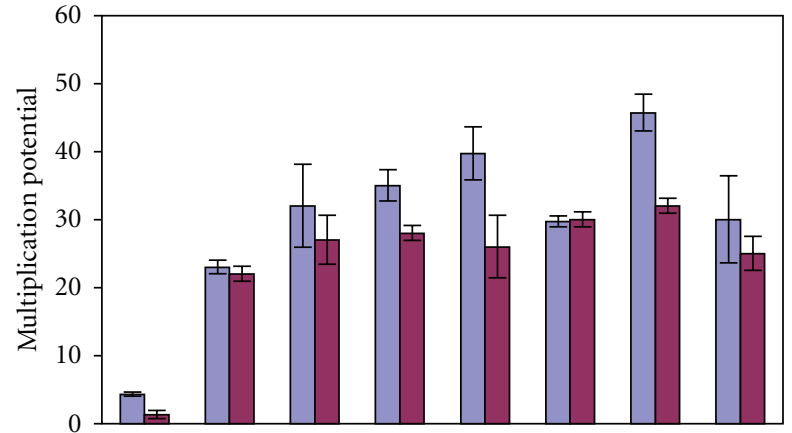

(a)

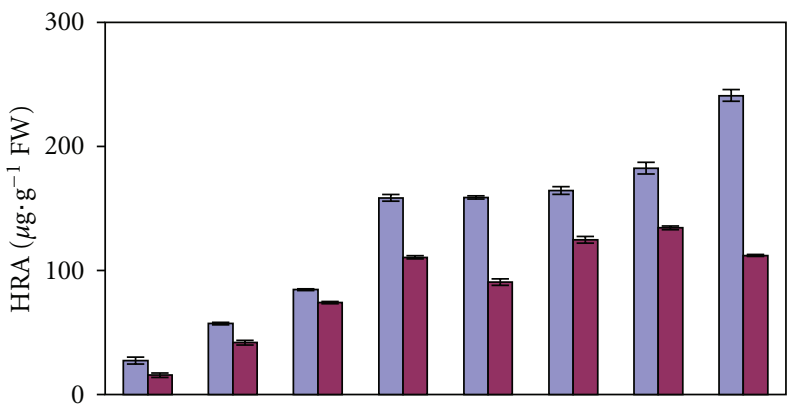

(c)

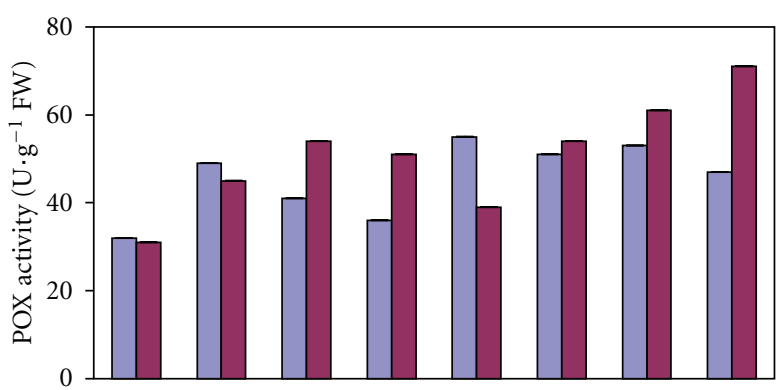

(e)

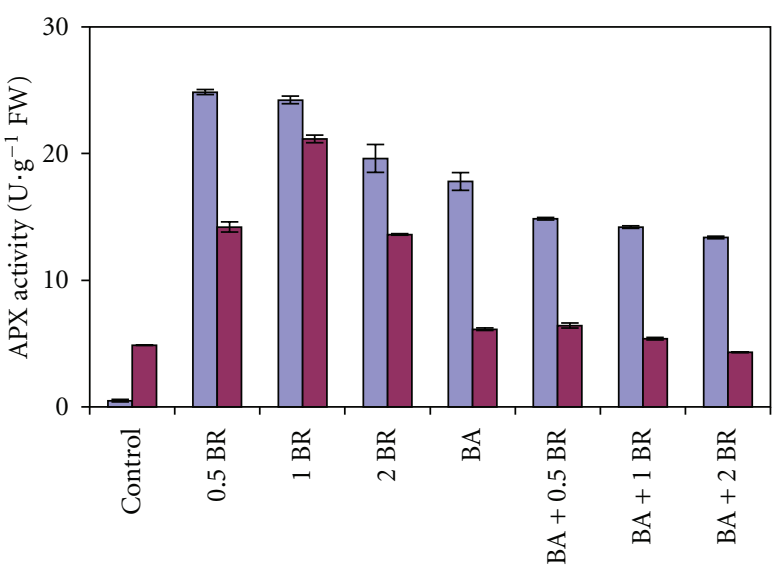

Concentration of PGRs

$\square \mathrm{M}-13$

口 PBS24030

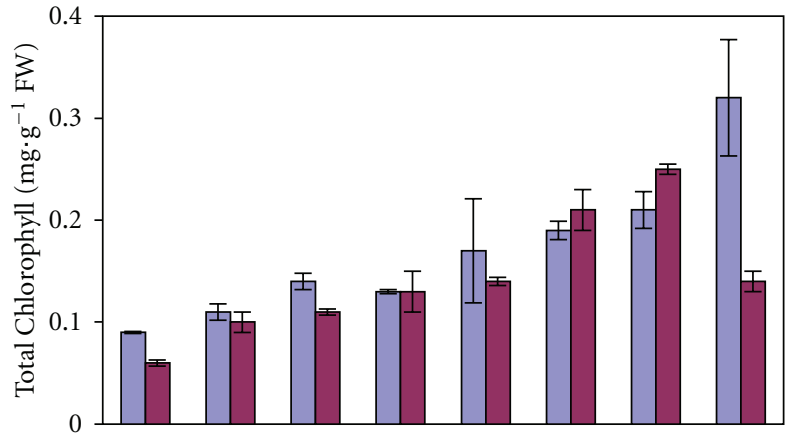

(b)

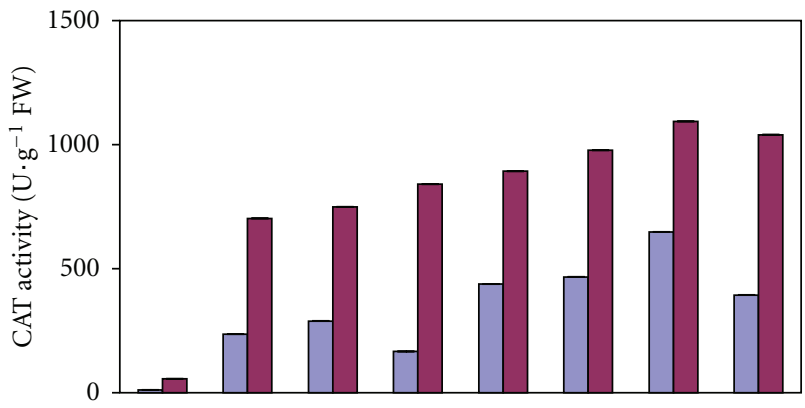

(d)

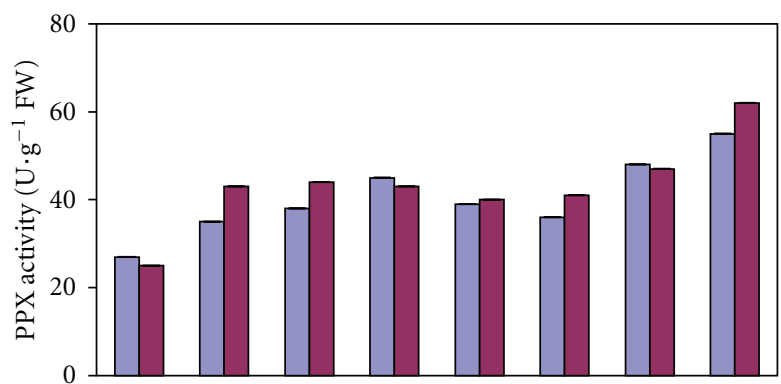

(f)

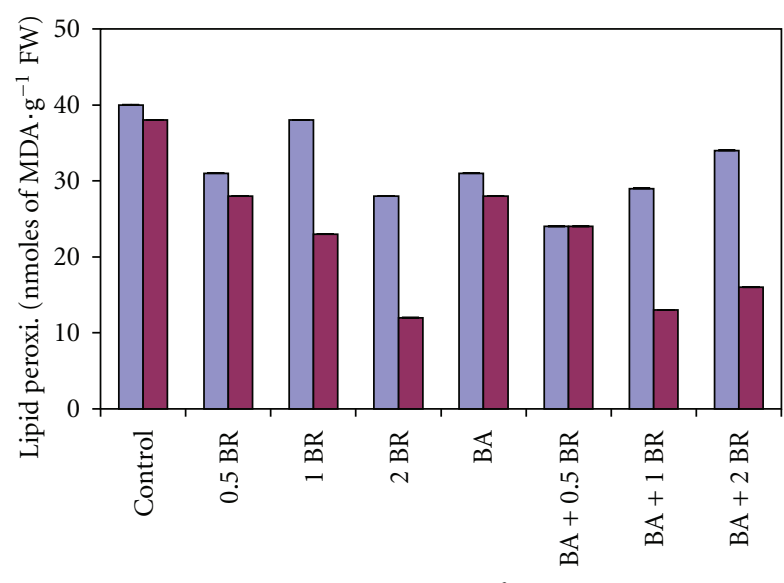

Concentration of PGRs

$\square \mathrm{M}-13$

— PBS24030

(g) 


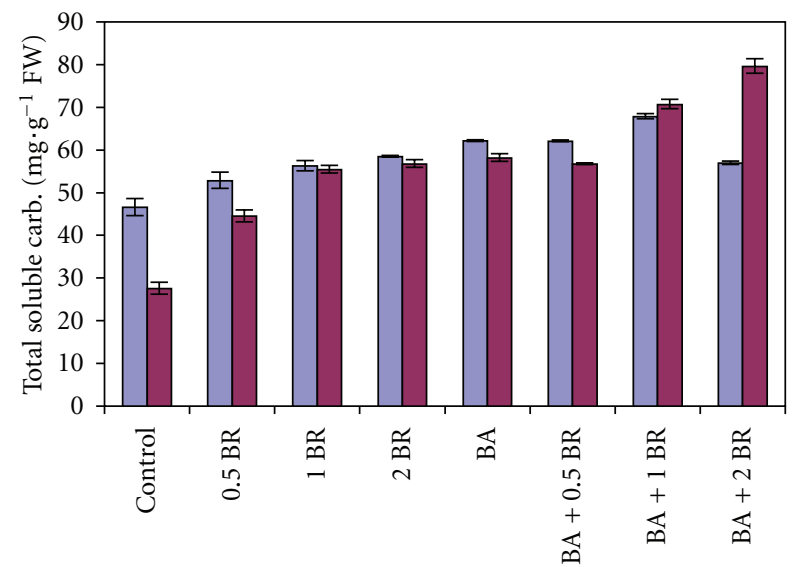

Concentration of PGRs

$\mathrm{M}-13$

PBS24030

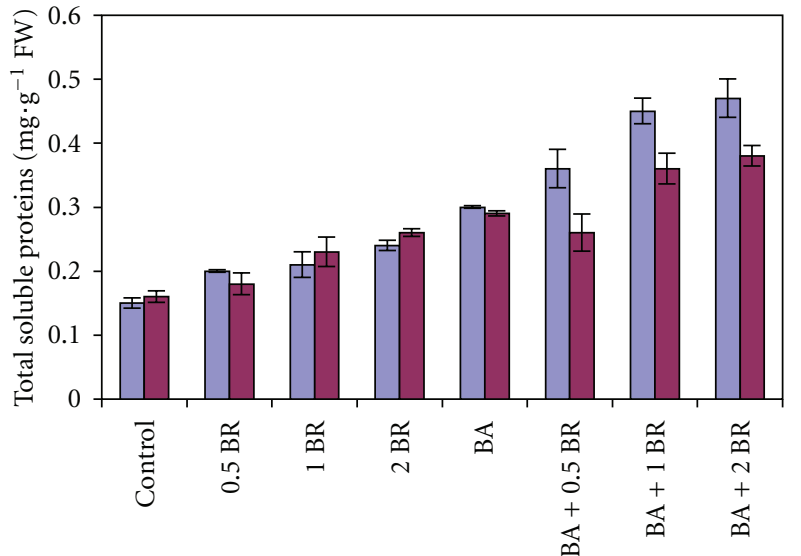

Concentration of PGRs

$\mathrm{M}-13$

PBS24030

(i)

(j)

Figure 1: Effect of Brassinosteroid (BR) at $0.5,1.0$ and $2.0 \mathrm{~mL} \mathrm{~L}^{-1}$ with or without 6-Benzyl Adenine (BA; $3 \mathrm{mg} \mathrm{L}^{-1}$ ) on in vitro; (a) shoot multiplication, (b) total chlorophyll content, (c) HRA, (d) catalase (CAT), (e) peroxidase (POX), (f) polyphenol oxidase (PPX), (g) ascorbate peroxidase (APX) activity, (h) lipid peroxidation, (i) total soluble carbohydrates and (j) protein content in M-13 and PBS24030 genotypes of groundnut. Bars represent the SE $(n=3)$.

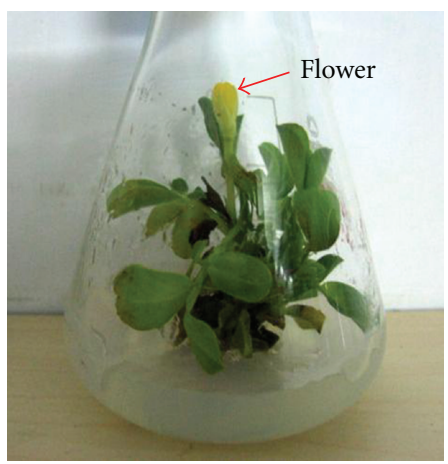

(a)

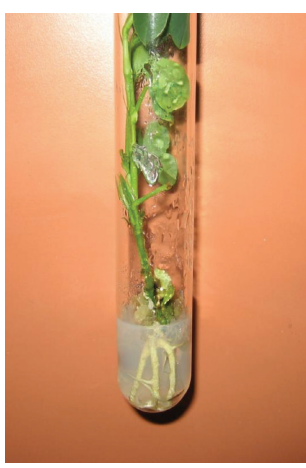

(b)

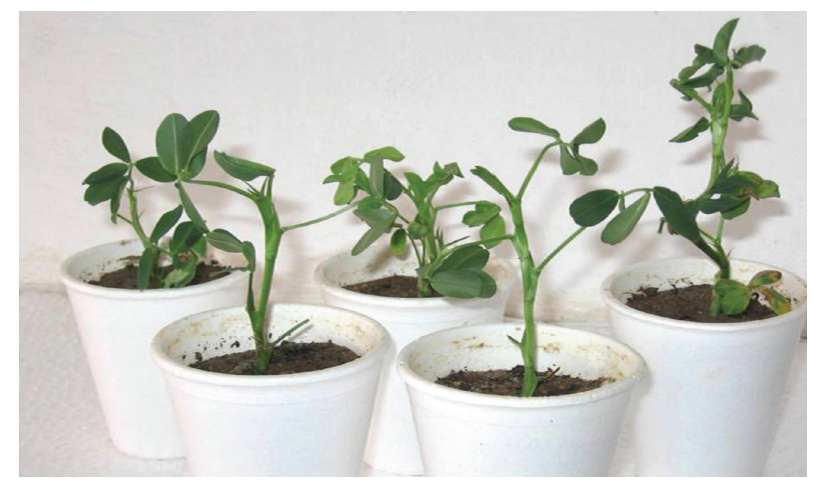

(c)

FIGURE 2: Response of Brassinosteroid (BR) alone and in combination with 6-Benzyl Adenine (BA, 3 mg L L $^{-1}$ ) at 30 DAI; (a) flowering in the genotype PBS24030 on the medium containing $2.0 \mathrm{~mL} \mathrm{~L}^{-1} \mathrm{BR}$ with $3 \mathrm{mg} \mathrm{L}^{-1} \mathrm{BA}$, (b) Rooting in M-13 cultivar on MS medium supplemented with $0.5 \mathrm{~mL} \mathrm{~L}^{-1} \mathrm{BR}$ alone, and (c) well-rooted plantlets in thermocol pots of M-13.

might be due to their genetic make-up. In the presence of $\mathrm{BA}\left(3 \mathrm{mg} \mathrm{L}^{-1}\right)$, shoot formation was observed at lower concentrations of BR indicating that the interaction of PGRs altered the shooting response. The differential effects of BRs on shoot formation and elongation was possibly dependant on the extent to which these molecules satisfied the structural requirements of BR receptors. These findings have practical applications in horticulture and forestry for the improvement of micropropagation techniques for usually hard-to-propagate woody and oilseed crops. It was observed in the present investigation that BR application at low concentrations resulted in rhizogenesis in both the groundnut cultivars. This observation was similar to that of Müssig et al. [27] who observed promotion of root growth in Arabidopsis by low concentrations of BR.
The enhancement in the chlorophyll content upon addition of $\mathrm{BR}$ to the culture medium indicated that photosynthetic process was likely to be affected by BR. In the literature, application of BRs has been shown to increase the total chlorophyll content and hence net photosynthetic rate in Brassica juncea [28, 29], Hibiscus sabdariffa [30], soybean seedlings [31], rice [32], and wheat [33]. A synergistic interaction between BR and BA was observed. However, the type of the applied BR is the main determinant in the manifestation of BRs effect on the content of photosynthetic pigments, and plant species is probably the second deciding factor. In contrast, the BR significantly affected neither the efficiency of photosynthetic electron transport nor the content of chlorophylls or carotenoids in two inbred lines of field-grown maize and their F1 hybrid [34]. 
Reactive oxygen species (ROS) are generated in plants during metabolism. Further, the accumulation of ROS is increased by environmental stresses. The ROS need to be scavenged for maintenance of normal growth. Plants have developed a series of enzymatic and nonenzymatic mechanisms to counteract ROS and protect cells from oxidative damage. Various enzymes including CAT, SOD, APX, guaiacol peroxidase, and PPX have been associated with detoxification of ROS in plants. Several PGRs including BRs have been reported to help in modulating this antioxidant defense system and thus scavenging the free radicals and help the plant to protect from oxidative stress. BRs affect the transcription and translation [35] thereby influencing the level of total proteins and enzymes [36].

An increase in CAT activity after treatment with BR has also been reported earlier in rice [11], groundnut [37], Zea mays L. [10, 38], tomato [39], Brassica juncea L. $[40,41]$, and so forth. It may be inferred from the enhancement in CAT activity that BR application modulated the antioxidative metabolism resulting in better growth of plants as suggested earlier [42, 43]. An increase in POX activity in response to the application of BRs has also been reported $[40,41,44]$. The POX has been implicated in the synthesis of lignin and other phenolic polymers. The enhancement in POX activity might defend the cells against harmful concentrations of hydroperoxides. Sirhindi et al. [41] also observed an increase in the activity of PPX after exogenous application of 28-homobrassinolide in seedlings of Brassica juncea L. Activity of APX was found to be consistent with the earlier reports in which APX activity was stimulated after the application of 24-epibrassinolide [39, 40, 45] and 2-homobrassinolide [46] and brassinolide analogue BR-16 [11]. The decline in MDA level indicated that BR treatment caused a decrease in lipid peroxidation in the in vitro grown leaves of groundnut plants. The decrease in MDA content after treatment with BR has been noticed earlier also but not much information is available in groundnut.

The rise in soluble proteins was more in M-13 cultivar than in PBS24030 which might be due to genotypic variations. Increased carbohydrate content was observed under the influence of BRs in tomato pericarp by Vardhini and Rao [47]. Wu et al. [48] also observed increased carbohydrate content due to $\mathrm{BR}$ in rice. An increase in soluble protein content might indicate that BR responses were dependent on protein synthesis as suggested by Kalinich et al. [49]. The application of BRs has been found to enhance protein content in normal plants as well as those subjected to different kinds of stress $[35,38,39,50,51]$. Vardhini and Rao $[42,43]$ reported that BRs substantially increased the growth of the plant which was associated with enhanced levels of DNA, RNA, soluble proteins, and carbohydrate. As higher contents of soluble carbohydrates and soluble proteins were likely to have positive correlation with plant growth, it might be inferred that BR treatment would stimulate growth in groundnut plants. It was supported by the observation that the number of shoots was highest in the cultures grown in the presence of BRs.

\section{Conclusion}

The data presented in this paper have demonstrated that BR can be effectively used for the direct organogenesis from the $\mathrm{CN}$ explant in both the cultivars. Experimental evidence indicated that in vitro effect of BR was involved in the alleviation of not only antioxidant capacity but also biochemical parameters. However, there are some differences in the responsive behaviors of the two groundnut cultivars in the presence of BR which may be attributed to the genetic differences. Our results clearly indicate that BR formulation, available as Double, is a potent plant growth regulator in various aspects.

\section{References}

[1] G. P. Savage and J. I. Keenan, "The composition and nutritive value of Groundnut Kernels," in The Groundnut Crop-A Scientific Basis for Improvement, J. Smartt, Ed., pp. 173-213, Chapman and Hall, London, UK, 1994.

[2] V. Khripach, V. Zhabinskii, and A. De Groot, "Twenty years of brassinosteroids: steroidal plant hormones warrant better crops for the XXI century," Annals of Botany, vol. 86, no. 3, pp. 441-447, 2000.

[3] L. L. Haubrick and S. M. Assmann, "Brassinosteroids and plant function: some clues, more puzzles," Plant, Cell and Environment, vol. 29, no. 3, pp. 446-457, 2006.

[4] S. Cao, Q. Xu, Y. Cao et al., "Loss-of-function mutations in DET2 gene lead to an enhanced resistance to oxidative stress in Arabidopsis," Physiologia Plantarum, vol. 123, no. 1, pp. 5766, 2005.

[5] J. Q. Yu, L. F. Huang, W. H. Hu et al., "A role for brassinosteroids in the regulation of photosynthesis in Cucumis sativus," Journal of Experimental Botany, vol. 55, no. 399, pp. 11351143, 2004.

[6] T. Montoya, T. Nomura, T. Yokota et al., "Patterns of Dwarf expression and brassinosteroid accumulation in tomato reveal the importance of brassinosteroid synthesis during fruit development," Plant Journal, vol. 42, no. 2, pp. 262-269, 2005.

[7] P. Sharma and R. Bhardwaj, "Effects of 24-epibrassinolide on growth and metal uptake in Brassica juncea L. under copper metal stress," Acta Physiologiae Plantarum, vol. 29, no. 3, pp. 259-263, 2007.

[8] P. Krishna, "Brassinosteroid-mediated stress responses," Journal of Plant Growth Regulation, vol. 22, no. 4, pp. 289-297, 2003.

[9] M. B. Wachsman, J. A. Ramırez, L. B. Talarico, L. R. Galagovsky, and C. E. Coto, "Antiviral activity of natural and synthetic brassinosteroids," Current Medicinal Chemistry, vol. 3, no. 2, pp. 163-179, 2004.

[10] R. Bhardwaj, N. Arora, P. Sharma, and H. K. Arora, "Effects of 28-homobrassinolide on seedling growth, lipid peroxidation and antioxidative enzyme activities under nickel stress in seedlings of Zea mays L," Asian Journal of Plant Sciences, vol. 6, no. 5, pp. 765-772, 2007.

[11] M. Nunez, P. Mazzafera, L. M. Mazorra, W. J. Siqueira, and M. A. Zullo, "Influence of brassinosteroid analogue on antioxidant enzymes in rice grown in culuture medium with NaCl," Plant Biology, vol. 47, pp. 67-70, 2003.

[12] F. Özdemir, M. Bor, T. Demiral, and I. Turkan, "Effects of 24epibrassinolide on seed germination, seedling growth, lipid peroxidation, proline concentration, and antioxidative system 
of rice under salinity stress," Plant Growth Regulation, vol. 42, pp. 203-211, 2004.

[13] A. Verma, C. P. Malik, Y. K. Sinsinwar, and V. K. Gupta, "Yield parameters responses in a spreading (cv. M-13) and semispreading (cv. Girnar-2) types of groundnut to six growth regulators," The American-Eurasian Journal of Agricultural Environmental Sciences, vol. 6, no. 1, pp. 88-91, 2009.

[14] T. Murashige and F. Skoog, "A revised medium for rapid growth and bioassays with tobacco tissue cultures," Plant Physiology, vol. 15, pp. 473-497, 1962.

[15] J. Coombs, D. O. Hall, S. P. Long, and J. M. O. Scurlock, Techniques in Bioproductivity and Photosynthesis, Pergamon International, Oxford, UK, 2nd edition, 1985.

[16] J. H. Cherry, Molecular Biology of Plants-A Text Manual, Colombia University Press, New York, NY, USA, 1973.

[17] H. Aebi, "Catalase in vitro," in Methods in Enzymology, L. Packer, Ed., vol. 105, pp. 121-126, Academic Press, New York, NY, USA, 1984.

[18] Y. Z. Zhu, S. H. Huang, B. K. H. Tan, J. Sun, M. Whitman, and Y. C. Zhu, "Antioxidants in Chinese herbal medicines: a biochemical perspective," Natural Product Reports, vol. 21, no. 4, pp. 478-489, 2004.

[19] M. Kar and D. Mishra, "Catalase, peroxidase and polyphenol oxidase activities during rice leaf senescence," Plant Physiology, vol. 57, pp. 315-319, 1976.

[20] E. F. I. B. Moshaty, S. M. Pike, A. J. Novacky, and O. P. Sehgal, "Lipid peroxidation and superoxide production in cowpea (Vigna unguiculata) leaves infected with tobacco ringspot virus or southern bean mosaic virus," Physiological and Molecular Plant Pathology, vol. 43, no. 2, pp. 109-119, 1993.

[21] K. M. Clegg, "Application of anthrone reagent to the estimation of starch in cereals," Journal of the Science of Food of Agriculture, vol. 7, pp. 40-44, 1956.

[22] O. H. Lowry, N. J. Rosebrough, A. L. Farr, and R. J. Randall, "Protein measurement with the Folin-phenol reagent," The Journal of Biological Chemistry, vol. 193, no. 1, pp. 265-275, 1951.

[23] Y. Hu, F. Bao, and J. Li, "Promotive effect of brassinosteroids on cell division involves a distinct $\mathrm{CycD} 3$-induction pathway in Arabidopsis," Plant Journal, vol. 24, no. 5, pp. 693-701, 2000.

[24] D. M. Zurek, D. L. Rayle, T. C. McMorris, and S. D. Clouse, "Investigation of gene expression, growth kinetics, and wall extensibility during brassinosteroid-regulated stem elongation," Plant Physiology, vol. 104, no. 2, pp. 505-513, 1994.

[25] A. B. Pereira-Netto, M. M. C. Carvalho-Oliverirs, J. A. Ramirez, and L. R. Galagovsky, "Shooting control in Eucalyptus grandis x E. urophylla hybrid: comparative effects of 28 -homocastasterone and a $5 \alpha$-monofluoro derivatives," Plant Cell, Tissue and Organ Culture, vol. 86, pp. 329-335, 2006.

[26] A. B. Pereira-Netto, C. T. A. Cruz-Silva, M. M. C. Schaefer, J. A. Ramirez, and L. R. Galagovsky, "Brassinosteroid- stimulated branch elongation in the Marubakaido apple rootatock," Trees-Structure and Function, vol. 20, pp. 286-291, 2006.

[27] C. Müssig, G. H. Shin, and T. Altmann, "Brassinosteroids promote root growth in Arabidopsis," Plant Physiology, vol. 133, no. 3, pp. 1261-1271, 2003.

[28] M. M. Alam, S. Hayat, B. Ali, and A. Ahmad, "Effect of 28-homobrassinolide treatment on nickel toxicity in Brassica juncea," Photosynthetica, vol. 45, no. 1, pp. 139-142, 2007.

[29] Q. Fariduddin, M. Yusuf, S. Hayat, and A. Ahmad, "Effect of 28-homobrassinolide on antioxidant capacity and photosynthesis in Brassica juncea plants exposed to different levels of copper," Environmental and Experimental Botany, vol. 66, no. 3, pp. 418-424, 2009.

[30] I. M. Talaat and A. A. Youssef, "Response of rossele plants (Hibiscus sabderiffa L.) to some growth regulating substances," Egyptian Journal of Physiological Sciences, vol. 22, pp. 327-338, 1998.

[31] G. Cevahir, S. Yentur, F. Eryilmaz, and N. Yilmazer, "Influence of brassinosteroids on pigment content of Glycine max L. (Soybean) grown in dark and light," Journal of Applied Biological Sciences, vol. 2, no. 1, pp. 23-28, 2008.

[32] M. Farooq, A. Wahid, S. M. A. Basra, and Islam-Ud-Din, "Improving water relations and gas exchange with brassinosteroids in rice under drought stress," Journal of Agronomy and Crop Science, vol. 195, no. 4, pp. 262-269, 2009.

[33] R. K. Sairam, G. C. Srivastava, S. Agarwal, and R. C. Meena, "Differences in antioxidant activity in response to salinity stress in tolerant and susceptible wheat genotypes," Biologia Plantarum, vol. 49, no. 1, pp. 85-91, 2005.

[34] M. Kočová, O. Rothová, D. Holá, M. Kvasnica, and L. Kohout, "The effects of brassinosteroids on photosynthetic parameters in leaves of two field-grown maize inbred lines and their F1 hybrid," Biologia Plantarum, vol. 54, no. 4, pp. 785-788, 2010.

[35] A. Bajguz, "Effect of brassinosteroids on nucleic acids and protein content in cultured cells of Chlorella vulgaris," Plant Physiology and Biochemistry, vol. 38, no. 3, pp. 209-215, 2000.

[36] Q. Fariduddin, A. Ahmed, and S. Hayat, "Response of Vigna radiata to foliar application of 28-homobrassinolide and Kinetin," Journal of Plant Biology, vol. 48, pp. 465-468, 2004.

[37] B. V. Vardhini and S. S. R. Rao, "Effect of brassinosteroids on the activities of certain oxidizing and hydrolyzing enzymes of groundnut," The Indian Journal of Plant Physiology, vol. 5, no. 1, pp. 89-92, 2000.

[38] N. Arora, R. Bhardwaj, P. Sharma, H. K. Arora, and P. Arora, "Amelioration of zinc toxicity by 28 -homobrassinolide in Zea mays L," The Canadian Journal of Pure and Applied Sciences, vol. 2, no. 3, pp. 503-509, 2008.

[39] M. Behnamnia, K. M. Kalantari, and F. Rezanejad, "Exogenous application of brassinosteroid alleviates drought-induced oxidative stress in Lycopersicon esculentum," General and Applied Plant Physiology, vol. 35, no. 1-2, pp. 22-34, 2009.

[40] P. Arora, R. Bhardwaj, and M. K. Kanwar, "24-epibrassinolide induced antioxidative defense system of Brassica juncea L. under Zn metal stress," Physiology and Molecular Biology of Plants, vol. 16, no. 3, pp. 285-293, 2010.

[41] G. Sirhindi, S. Kumar, R. Bhardwaj, and M. Kumar, "Effects of 24-epibrassinolide and 28-homobrassinolide on the growth and antioxidant enzyme activities in the seedlings of Brassica juncea L," Physiology and Molecular Biology of Plants, vol. 15, no. 4, pp. 335-341, 2009.

[42] B. V. Vardhini and S. S. R. Rao, "Effect of 28-homobrassinolide on growth, metabolite content and yield of groundnut (Arachis hypogaea. L)," The Indian Journal of Plant Physiology, vol. 13, pp. 58-60, 1998.

[43] B. V. Vardhini and S. S. Ram Rao, "Effect of brassinosteroids on growth, metabolite content and yield of Arachis hypogaea," Phytochemistry, vol. 48, no. 6, pp. 927-930, 1998.

[44] P. Sharma, R. Bhardwaj, N. Arora, and H. K. Arora, "Effect of 28-homobrassinolide on growth, zinc metal uptake and antioxidative enzyme activities in Brassica juncea L. seedlings," Brazilian Journal of Plant Physiology, vol. 19, no. 3, pp. 203210, 2007.

[45] L. M. Mazorra, M. Nunez, M. Hechavarria, F. Coll, and M. J. Sanchez- Blanco, "Influence of brassinosteroids on 
antioxidant enzymes activity in tomato under different temperatures," Plant Biology, vol. 45, pp. 593-596, 2002.

[46] G. Kartal, A. Temel, E. Arican, and N. Gozukirmizi, "Effects of brassinosteroids on barley root growth, antioxidant system and cell division," Plant Growth Regulation, vol. 58, no. 3, pp. 261-267, 2009.

[47] B. V. Vardhini and S. S. R. Rao, "Acceleration of ripening of tomato pericarp discs by brassinosteroids," Phytochemistry, vol. 61, no. 7, pp. 843-847, 2002.

[48] C. Y. Wu, A. Trieu, P. Radhakrishnan et al., "Brassinosteroids regulate grain filling in rice," Plant Cell, vol. 20, no. 8, pp. 2130-2145, 2008.

[49] J. F. Kalinich, N. B. Mandava, and J. A. Todhunter, "Relationship of nucleic acid metabolism to brassinolide induced responses in beans," Journal of Plant Physiology, vol. 120, pp. 207-214, 1985.

[50] S. Anuradha and S. S. R. Rao, "Application of brassinosteroids to rice seeds (Oryza sativa L.) reduced the impact of salt stress on growth, prevented photosynthetic pigment loss and increased nitrate reductase activity," Plant Growth Regulation, vol. 40, no. 1, pp. 29-32, 2003.

[51] M. Shahbaz, M. Ashraf, and H. U. R. Athar, "Does exogenous application of 24-epibrassinolide ameliorate salt induced growth inhibition in wheat (Triticum aestivum L.)?” Plant Growth Regulation, vol. 55, no. 1, pp. 51-64, 2008. 


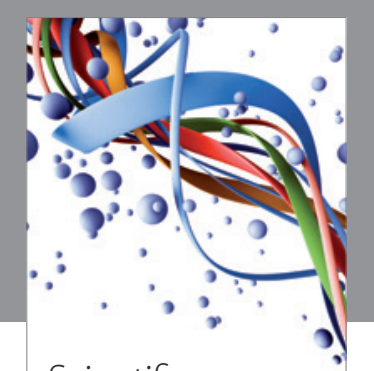

Scientifica
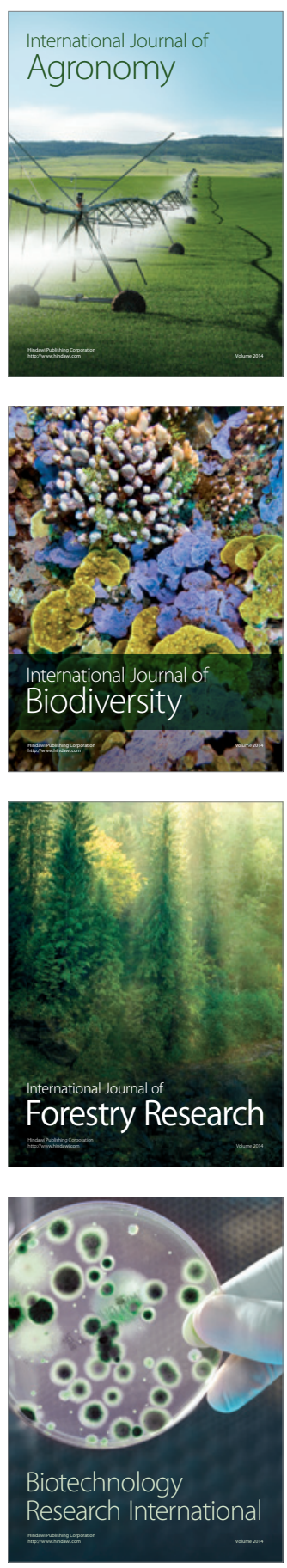
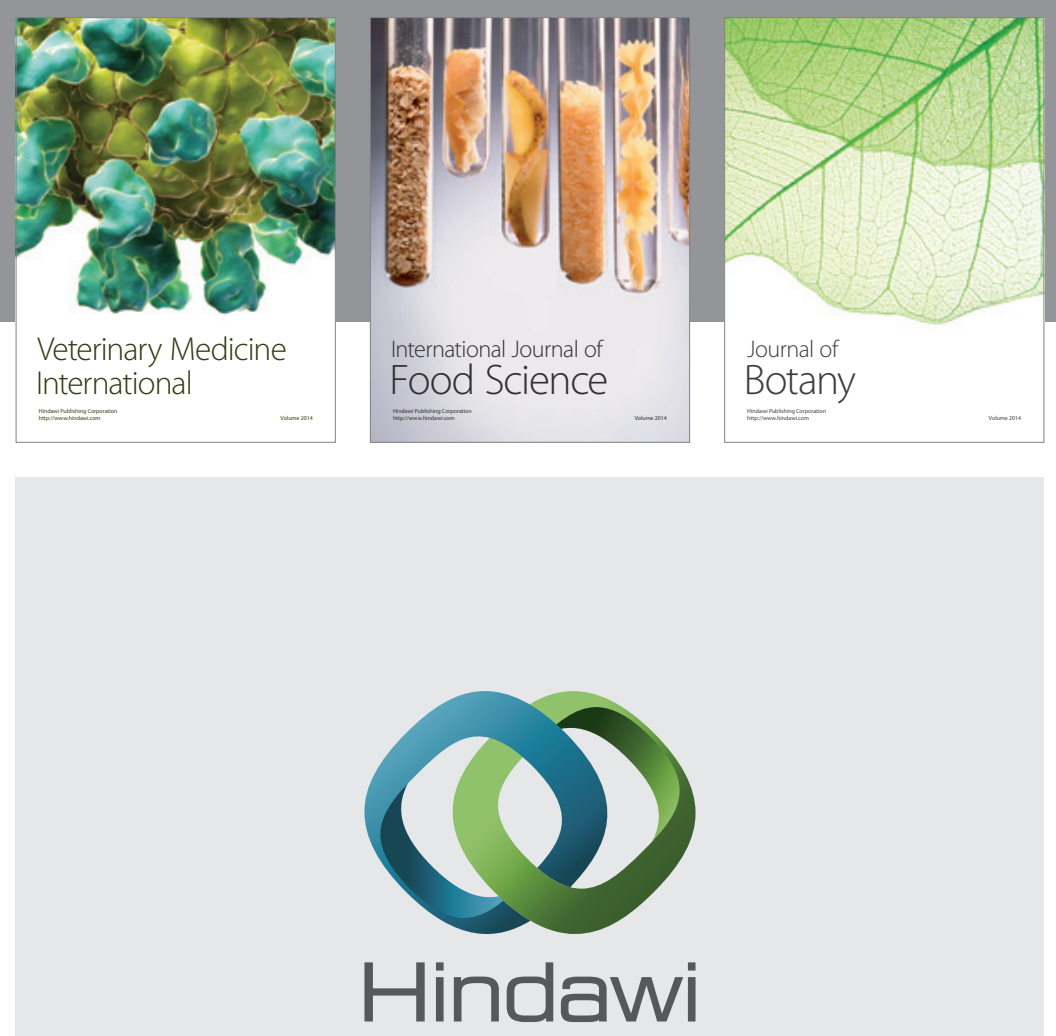

Submit your manuscripts at

http://www.hindawi.com
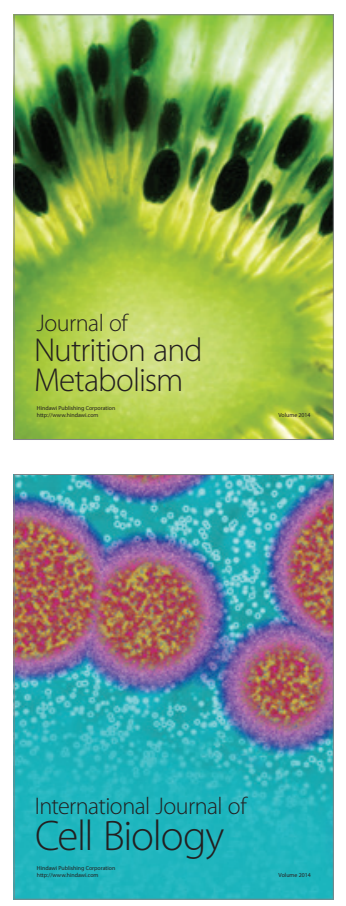
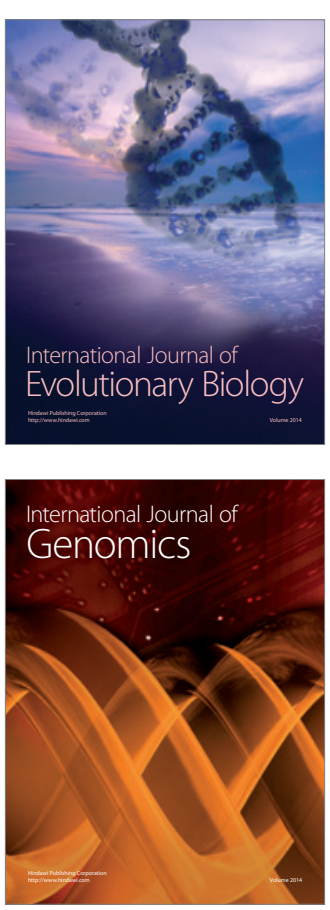
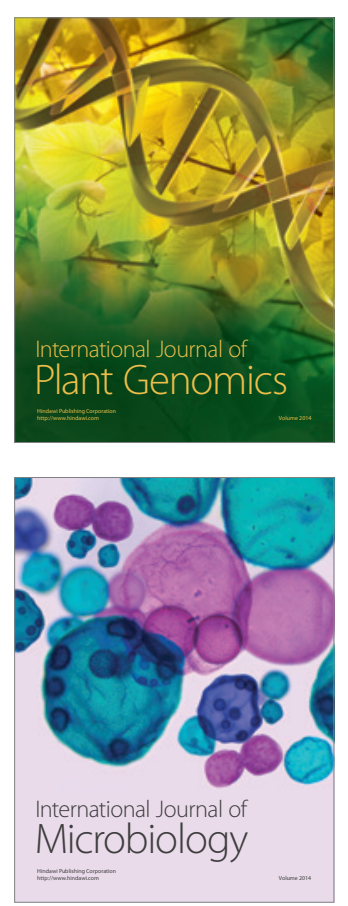

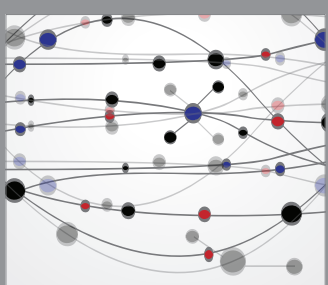

The Scientific World Journal
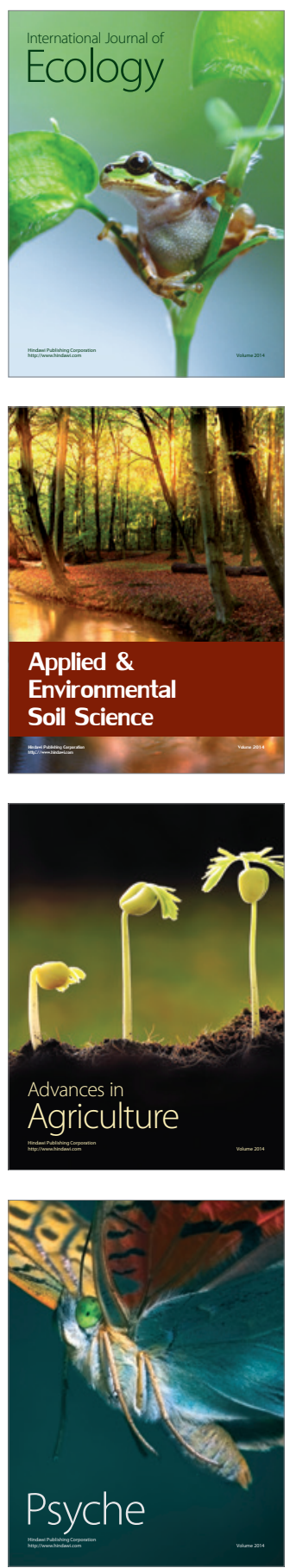